\title{
Preservice and Inservice Secondary Teachers' Orientations Toward Content Area Reading
}

\author{
BONNIE C. KONOPAK
}

Louisiana State University

\author{
JOHN E. READENCE \\ University of Nevada at Las Vegas
}

ELIZABETH K. WILSON

University of Alabama

\begin{abstract}
This study examined preservice and inservice secondary teachers' orientations toward content area reading and instruction. Instruments included two sets of belief statements and three sets of lesson plans; for comparison, each instrument incorporated three explanations of the reading process. Based on their selection of statements and plans, preservice teachers favored an interactive model of reading but a reader-based instructional approach, whereas inservice teachers held reader-based beliefs in both areas. In addition, both groups selected primarily reader-based vocabulary and comprehension lessons but varied in their choices of decoding lessons. Further, only teachers holding reader-based beliefs consistently chose corresponding vocabulary and comprehension plans.
\end{abstract}

D uring the past 15 years, research on teacher effectiveness has shifted its focus from just observing behaviors in the classroom to examining the relationship between the way teachers think and what they practice (Clark \& Peterson, 1986; Shavelson \& Stern, 1981; Shulman, 1986). The underlying assumption is that teachers' thoughts about different components of the instructional process can influence their classroom plans and actions (Armour-Thomas, 1989). As one in a series of investigations on the belief-practice relationship, we attempted to determine the theoretical orientations of preservice and inservice secondary teachers regarding content area reading and instruction. By focusing on these two groups, we examined how academic and professional experience might influence teachers' thoughts and decisions as a basis for future research on classroom practices.

Research on teaching was once dominated by a unidirectional, process-product approach that focused on classroom behaviors and achievement; current research has developed a broad, recursive approach involving teachers' beliefs, decision making, and interactions with students (see Clark \& Peterson, 1986, for a review). In particular, teachers' beliefs regarding teaching and learning are considered critical components supporting the planning and implementation stages of instruction. By examining these beliefs, researchers can address their influence on, and how they are influenced by, classroom events.

In reading education, the extent to which teachers' thoughts influence instructional decision making and behavior has been debated. One position suggests that teachers do possess theoretical beliefs toward reading and that their plans and subsequent actions are filtered through these understandings. As Harste and Burke (1977) stated "Despite atheoretical statements, teachers are theoretical in their instructional approach to reading" (p. 32). Subsequent research (Richardson, Anders, Tidwell, \& Lloyd, 1991; Rupley \& Logan, 1984; Stern \& Shavelson, 1983) supported this premise, indicating that methods and materials are selected or ignored based on teachers' beliefs about reading and learning processes. As an illustration, Richardson et al. found that upper elementary teachers' beliefs, as assessed in ethnographic interviews, were consistent with their reading comprehension instruction; for example, teachers who believed reading involved learning a set of skills regularly used basal texts and focused on different word-attack approaches.

However, other investigators (Duffy \& Ball, 1986; Lampert, 1985) emphasized factors external to the teacher, which can be even more influential. Here, the focus was on the sociocultural and environmental realities of the classroom that can constrain the implementation of belief-supported instruction. As Duffy and Anderson (1982) noted, although teachers can state theoretical aspects related to reading and instruction, their practice is actually governed by complex, contextual variables. For example, Hoffman and Kugle (1982) found that teachers' verbal feedback to students during

Address correspondence to Bonnie C. Konopak, Office of the Dean, Louisiana State University, 221 Peabody Hall, Baton Rouge, LA 70803-4707. 
reading instruction was not consistent with their beliefs about the reading process and concluded that decisions made regarding instruction were generally situational.

To further examine this issue, Kinzer (1988) compared the beliefs and instructional choices of preservice and inservice elementary teachers regarding the reading process. He hoped to discern how experience affected these teachers' beliefs, as well as the consistency between their beliefs and choices of instruction. For comparison, he used two written instruments (Kinzer \& Carrick, 1986): (a) two sets of belief statements on how reading takes place (theoretical model) and how reading develops (instructional approach) and (b) three sets of lesson plans on syllabication, vocabulary, and comprehension (specific application). Each set was constructed to incorporate three divergent explanations of the reading process: text based (Gough, 1985); reader based (Goodman, 1985), and interactive (Rumelhart, 1985). According to Leu and Kinzer (1987), these three explanations represent different points on a continuum of explanations; text-based and reader-based plans are situated near the ends, and interactive plans are situated "somewhere in the middle" (p. 39) and related to both. (Note that although Kinzer used different labels for explanations in different instruments, for the purposes of this study, we used one set of labels across instruments.)

The explanations for how reading takes place differed by source of meaning and role of the reader. That is, (a) text-based plans assumed that meaning resides in the text for the reader to attain, (b) reader-based explanations assumed that meaning resides in the reader who encounters the text, and (c) interactive plans assumed that meaning resides in the text and in the reader who uses both written and experiential information to make meaning. The explanations for how reading develops differed by the nature and delivery of instruction. That is, (a) text-based plans assumed that instruction focuses on mastery of separate, sequential skills; (b) readerbased explanations assumed that instruction holistically involves all language processes; and (c) interactive plans assumed that instruction is differentially delivered depending on different stages of development. Aspects of both how reading takes place and develops were represented for the three sets of lesson plans. That is, text-based plans focused on a teacher-directed, discrete skills lesson; reader-based plans emphasized a studentcentered, whole language lesson; and interactive plans emphasized a teacher-directed lesson based on individual student differences.

Based on his subjects' choices of statements and lessons, Kinzer (1988) found that the two groups were similar in their beliefs about the reading process, but to different degrees. That is, preservice teachers primarily chose reader-based explanations, whereas the inservice teachers were more equally distributed between readerbased and interactive explanations. In addition, in ex- amining the correspondence between the teachers' beliefs and lesson choices, Kinzer found that teachers in both groups who held reader-based beliefs were generally consistent in choosing corresponding lesson plans, although preservice teachers were more consistent than inservice teachers across all instruments. He concluded that, similar to Duffy and Anderson's (1982) findings, the practicing teachers' responses and inconsistencies may have been influenced somewhat by their actual experiences in the classroom, whereas the preservice teachers' views may have been more unified because of their lack of experience.

In the present study we attempted to determine the beliefs and decisions of preservice and inservice secondary teachers regarding content area reading and instruction. By addressing this population, we hoped not only to extend Kinzer's (1988) findings but also to develop a basis for future research on the relationship between theoretical beliefs and actual practice. The major questions addressed were: (a) Do preservice and inservice teachers hold different theoretical orientations concerning reading and instruction in the content areas? and (b) Are preservice and inservice teachers consistent in their theoretical orientations concerning the reading process and instructional decision making?

\section{Method}

\section{Subjects}

Subjects for this study were 58 preservice and 46 inservice secondary teachers enrolled in education courses at a large southeastern university. Approximately $65 \%$ of the preservice teachers were women and $35 \%$ were men; $25 \%$ were juniors, $55 \%$ seniors, and $20 \%$ postbaccalaureate students. These subjects were enrolled in two sections of a required undergraduate content reading methods course that were taught by the same instructor. Approximately $70 \%$ of the inservice teachers were women; they were enrolled in eight graduate-level secondary education courses that were taught by different instructors. Based on identical course questionnaires, preservice teachers indicated no prior field or teaching experience, whereas inservice teachers indicated 1 through 15 years of teaching experience. In addition, the two groups indicated the same eight subject area specialties: English, fine arts, foreign language, mathematics, physical education, science, social studies, and vocational education.

\section{Materials}

Kinzer's (1988) instruments were adapted to reflect a content area emphasis appropriate for use with secondary teachers. The two sets of belief statements on how reading takes place and how it develops each contained 15 statements, 5 text based, 5 reader based, and 5 in- 
teractive. All were modified through minor wording changes. For example, an original statement on how reading takes place read: "There is usually only one acceptable answer to a question from a story," whereas the revised statement read: "There is usually only one acceptable answer to a question from a text." In addition, an original statement on how reading develops read: "Children should receive many opportunities to read materials unrelated to specific school learning tasks," whereas the revised statement read: "Students should receive many opportunities to read materials other than the textbook in the content areas (e.g. newspapers, literature, magazines, etc." (See Appendix A for the two complete sets of belief statements.)

The three sets of lesson plans on decoding, vocabulary, and instruction were written according to the format of the original plans, outlining student and teacher behaviors as well as instructional activities. Each set contained a text-based, a reader-based, and an interactive plan. Briefly, text-based plans stressed that (a) the text is the primary source of information, (b) the students learn through drill and practice of individual skills, and (c) the teacher stipulates the correctness of student responses. Reader-based plans emphasized that (a) the students bring meaning to the text, (b) the students use their prior knowledge to anticipate and confirm their understanding; and (c) the teacher models and guides the lessons. Interactive plans stressed that (a) the students use both text information and personal knowledge to develop meaning, (b) the students use a variety of reading strategies that are appropriate for them, and (c) the teacher directs the lessons but allows for individual student differences. (See Appendix B for the complete lesson set on vocabulary instruction.)

Validity. To establish content validity, we asked two professors and two doctoral students in reading education to classify the belief statements and lessons according to the different explanations and to offer suggestions for revisions. Among the raters and researchers, there was .91 agreement on the classification of statements and .96 agreement on the classification of lesson plans. Based on suggestions, we revised six belief statements: Three statements were rewritten to distinguish between reader-based and interactive explanations, and three statements were rewritten to reflect differences between text-based and interactive explanations. In addition, on the decoding instructional lesson set, wording changes were made to more clearly distinguish readerbased and interactive lessons.

Reliability. To establish relability, we conducted a test-retest procedure that examined the consistency of teachers' theoretical orientations across two versions of the instruments. The participants included 125 preservice and inservice content teachers representing 10 subject areas. All were enrolled in summer school education courses; preservice teachers in undergraduate classes and inservice teachers in graduate classes. Based on course questionnaires, preservice teachers had no prior classroom experience, whereas inservice teachers had 2 through 20 years' teaching experience.

All the teachers were randomly assigned one version of the instruments during the first week of class and the alternate version, with statements and lessons reordered, during the second week of class. The procedure for administration and scoring was identical to that used in the study (see the Procedure section). Consistency of theoretical orientations across versions was determined by percentage of agreement for each teacher group. Across instruments, consistency was .86 for all teachers, .84 for preservice teachers, and .89 for inservice teachers.

\section{Procedure}

The procedure for data collection was the same for both preservice and inservice teachers. Two researchers administered the instruments in the subjects' university classrooms. Subjects first were given the 15 belief statements on how content reading takes place and were asked to circle 5 statements that best represented their beliefs in that area. Next, they performed the identical task concerning their beliefs about how reading develops in the content areas. Finally, they were asked to choose one lesson each for decoding, vocabulary, and comprehension instruction that they ideally would use with an average content class. The instrumentation for preservice teachers was administered at the beginning of the first class of the semester; the instrumentation for inservice teachers was administered at the beginning of class within the first 2 weeks of the same semester. All the subjects completed the instruments within $30 \mathrm{~min}$.

Scoring. Following Kinzer's (1988) procedure, we scored each set of instruments to classify subjects' beliefs and lesson choices as representative of a particular explanation of reading. For the two sets of belief statements, teachers choosing a majority of statements that reflected one explanation (i.e., text based, reader based, interactive) were classified as that explanation. In addition, teachers choosing a distribution of statements that reflected more than one explanation were classified as interactive; as noted earlier, this explanation related to both text-based and reader-based views and reflects components of each (Leu \& Kinzer, 1987). (See Appendix $C$ for the frequency of statements chosen.) For the three sets of lesson plans, teachers choosing a particular lesson (e.g., text based) in each instructional area were classifed as that explanation.

\section{Results}

\section{Group Differences on Theoretical Orientations}

For Research Question 1, we conducted chi-square statistics to examine differences between preservice and 
inservice teachers on their theoretical orientations, using $2 \times 3$ (Teacher Groups $\times$ Explanations) contingency tables for the two sets of belief statements and the three sets of lesson plans. When global significant differences were found, we conducted post hoc chi-square analyses (Marascuilo, 1966) to determine the source of the significance.

Beliefs about the reading process. Preservice and inservice teachers varied in their orientations concerning how reading takes place but were similar in their orientations about how reading develops (see Table 1). On how reading takes place, a statistically significant difference was found between groups; our findings on post hoc tests indicated that preservice teachers chose more interactive explanations, whereas inservice teachers

Table 1.-Frequencies and Chi-Square Values of Belief Statement Orientations for Preservice and Inservice Teachers

\begin{tabular}{|c|c|c|c|}
\hline & Text based & $\begin{array}{c}\text { Reader } \\
\text { based }\end{array}$ & Interactive \\
\hline Teachers & $\%$ & $\%$ & $\%$ \\
\hline
\end{tabular}

\begin{tabular}{lccccccc}
\hline \multicolumn{8}{c}{ How reading takes place } \\
Preservice & 1 & 2 & 16 & $28 \dagger$ & 41 & $70 \dagger$ & \\
Inservice & 0 & 0 & 26 & 57 & 20 & 43 & $8.20^{*}$ \\
\hline
\end{tabular}

\begin{tabular}{lccccccc}
\hline \multicolumn{7}{c}{ How reading develops } \\
Preservice & 4 & 7 & 32 & 55 & 22 & 38 & \\
Inservice & 2 & 4 & 34 & 74 & 10 & 22 & 4.00 \\
\hline
\end{tabular}

Note. Preservice $n=58$; inservice $n=46$.

${ }^{*} p<.05$.

$\Varangle$ Post hoc significant at $p<.05$

Table 2.-Frequencies and Chi-Square Values of Lesson-Plan Orientations for Preservice and Inservice Teachers

\begin{tabular}{|c|c|c|c|c|c|c|c|}
\hline \multirow[b]{2}{*}{ Variable } & \multicolumn{2}{|c|}{ Text based } & \multicolumn{2}{|c|}{$\begin{array}{c}\text { Reader } \\
\text { based }\end{array}$} & \multicolumn{2}{|c|}{ Interactive } & \multirow[b]{2}{*}{$x^{2}$} \\
\hline & $n$ & $\%$ & $n$ & $\overline{\%}$ & $n$ & $\%$ & \\
\hline \multicolumn{8}{|l|}{ Decoding } \\
\hline Preservice & 28 & 48 & 12 & 21 & 18 & 31 & \multirow{2}{*}{2.92} \\
\hline Inservice & 16 & 35 & 16 & 35 & 14 & 30 & \\
\hline \multicolumn{8}{|l|}{ Vocabulary } \\
\hline Preservice & 17 & 29 & 30 & 52 & 11 & 19 & \multirow{2}{*}{5.49} \\
\hline Inservice & 5 & 11 & 27 & 59 & 14 & 30 & \\
\hline \multicolumn{8}{|c|}{ Comprehension } \\
\hline Preservice & 5 & 09 & 38 & $66 \dagger$ & 15 & 25 & \multirow{2}{*}{$8.59^{*}$} \\
\hline Inservice & 0 & 00 & 41 & 89 & 5 & 11 & \\
\hline
\end{tabular}

Note. Preservice $n=58$; inservice $n=46$.

${ }^{*} p<.05$.

$\dagger$ Post hoc significant at $p<.05$ selected more reader-based explanations. We found no statistically significant difference on how reading develops; both groups primarily chose a reader-based instructional approach.

Lesson plan choices. A statistically significant difference between groups was found only for the comprehension lesson plan set; inservice teachers selected more reader-based plans than did preservice teachers (see Table 2). For decoding lessons, both preservice and inservice teachers were distributed across the three explanations, whereas for vocabulary lessons, the two groups were primarily reader based.

\section{Match Between Reading Beliefs and Lesson Choices}

For Research Question 2, we conducted separate chisquare analyses to examine the match between each teacher group's beliefs about reading and its instructional choices. Analyses included $1 \times 2$ (Belief $\times$ Lesson Match/Not Match) contingency tables for each possible belief and lesson combination.

Preservice teachers. Table 3 provides the frequency of belief-lesson match for preservice teachers. We found statistically significant results for how reading takes place for reader-based explanations and vocabulary and comprehension lessons. That is, those teachers favoring a reader-based model of reading chose more readerbased vocabulary and comprehension lessons. For how reading develops, we found similar results; only teachers holding reader-based beliefs selected more corresponding vocabulary and comprehension plans. No statistical significance was found for other belief-lesson combinations.

Table 3.-Frequencies of Belief-Lesson Match and Chi-Square Values for Preservice Teachers

\begin{tabular}{lccc}
\hline \hline & $\begin{array}{c}\text { Text based } \\
\text { (out of 1 } \\
\text { possible } \\
\text { match) }\end{array}$ & $\begin{array}{c}\text { Reader based } \\
\text { (out of 16 } \\
\text { possible } \\
\text { matches) }\end{array}$ & $\begin{array}{c}\text { Interactive } \\
\text { (out of 41 } \\
\text { possible } \\
\text { matches) }\end{array}$ \\
\hline How reading takes place & \\
$\begin{array}{l}\text { Decoding } \\
\text { Vocabulary }\end{array}$ & 0 & 4 & 12 \\
Comprehension & 1 & $11^{*}$ & 10 \\
\hline \hline & 0 & $13^{* *}$ & 12 \\
\hline & $\begin{array}{c}\text { Text based } \\
\text { (out of 4 } \\
\text { possible } \\
\text { matches) }\end{array}$ & $\begin{array}{c}\text { Reader based } \\
\text { (out of 32 } \\
\text { possible } \\
\text { matches) }\end{array}$ & $\begin{array}{c}\text { Interactive } \\
\text { (out of 22 } \\
\text { possible } \\
\text { matches) }\end{array}$ \\
\hline & How reading develops & \\
Decoding & 2 & 6 & 5 \\
Vocabulary & 1 & $19^{* * *}$ & 4 \\
Comprehension & 1 & $23^{* * * *}$ & 7 \\
\hline
\end{tabular}

Note. Preservice $n=58$.

${ }^{*} \chi^{2}=8.59, p<.01 ; * * \chi^{2}=15.91, p<.001 ; * * * \chi^{2}=9.41, p<.01 ;{ }^{* * * *} \chi^{2}=$ $20.84, p<.001$. 
Table 4.-Frequencies of Belief-Lesson Match and Chi-Square Values for Inservice Teachers

\begin{tabular}{|c|c|c|c|}
\hline & $\begin{array}{l}\text { Text based } \\
\text { (out of } 0 \\
\text { possible } \\
\text { matches) }\end{array}$ & $\begin{array}{c}\text { Reader based } \\
\text { (out of } 26 \\
\text { possible } \\
\text { matches) }\end{array}$ & $\begin{array}{c}\text { Interactive } \\
\text { (out of } 20 \\
\text { possible } \\
\text { matches) }\end{array}$ \\
\hline \multicolumn{4}{|c|}{ How reading takes place } \\
\hline Decoding & - & 10 & 7 \\
\hline Vocabulary & - & $16^{*}$ & 7 \\
\hline \multirow[t]{2}{*}{ Comprehension } & - & $24 * *$ & 3 \\
\hline & $\begin{array}{l}\text { Text based } \\
\text { (out of } 2 \\
\text { possible } \\
\text { matches) }\end{array}$ & $\begin{array}{c}\text { Reader based } \\
\text { (out of } 34 \\
\text { possible } \\
\text { matches) }\end{array}$ & $\begin{array}{c}\text { Interactive } \\
\text { (out of } 10 \\
\text { possible } \\
\text { matches) }\end{array}$ \\
\hline \multicolumn{4}{|c|}{ How reading develops } \\
\hline Decoding & 2 & 14 & 1 \\
\hline Vocabulary & 1 & $23 * * *$ & 4 \\
\hline Comprehension & 0 & $30 * * * *$ & 1 \\
\hline
\end{tabular}

Note. Inservice $n=46$.

${ }^{*} \chi^{2}=8.92, p<.01 ;{ }^{* *} \chi^{2}=39.83, p<.0001 ;{ }^{* * *} \chi^{2}=17.54, p<.001 ;{ }^{* * * *} \chi^{2}$ $=45.35, p<.0001$.

Inservice teachers. We found similar results on belief-lesson matches for inservice teachers (see Table 4). For both how reading takes place and how reading develops, those teachers choosing a reader-based model of reading selected significantly more corresponding reader-based vocabulary and comprehension lessons. Again, other belief-lesson combinations were not statistically significant.

\section{Discussion}

The purpose of the present investigation was to examine preservice and inservice secondary teachers' theoretical orientations regarding reading and instruction in the content areas. The findings are limited by the hypothetical nature of the written tasks; teachers were not studied in real instructional situations where decisions might be made differently. In addition, we examined only three broad theoretical orientations that we predetermined; discrete beliefs as reflected by individual statement selections were not analyzed. Further, these subjects were studied only in relation to their degree of teaching experience; possible differences among the eight content areas represented were not examined. Given these limitations, the results indicate that the groups varied somewhat in their orientations across instruments but were similar in their consistency between beliefs and lesson choices.

The first research question on the theoretical orientations of preservice and inservice teachers indicated differences between groups, as well as within groups, across instruments. On the belief statements, preservice teachers favored an interactive explanation of how reading takes place, whereas inservice teachers selected a reader-based explanation; however, both groups primarily chose a reader-based explanation of how reading develops. Such results indicate preservice teachers' lack of unity in their orientations toward a reading model and an instructional approach, whereas inservice teachers showed more consistency. It may be that these inservice teachers had developed unified explanations of the reading process based on their background in education course work and their teaching experiences, whereas the preservice teacher had not yet had these opportunities.

However, preservice and inservice teachers were more similar in their lesson choices. For decoding lessons, both groups were distributed across the three explanations, varying somewhat in their proportions of textbased, reader-based, and interactive orientations. These responses may have been caused by a lack of emphasis on decoding as a skill in secondary education course work, as well as actual teaching, so that these groups relied more on traditional or mixed approaches. For vocabulary and comprehension instruction, both groups primarily favored reader-based lessons, corresponding with these teachers' beliefs about an instructional approach or how reading develops. In particular, inservice teachers were overwhelmingly reader based on comprehension, suggesting a strong academic and teaching emphasis in this instructional area.

The second research question on the consistency between teachers' beliefs about the reading process and their instructional choices showed statistically significant results only for reader-based orientations and corresponding vocabulary and comprehension lessons. For inservice teachers, these results were not unexpected given the high percentage of responses for these orientations (see Tables 1 and 2). For preservice teachers, the results were somewhat surprising; although their orientation on how reading develops was primarily reader based, their orientation on how reading takes place was interactive. Again, it may be that preservice teachers had not yet developed unified explanations of how reading takes place and actual instruction. Further, an interactive explanation may lie on a continuum between text-based and reader-based explanations and thus is somewhat related to both (Leu \& Kinzer, 1987). Consequently, while teachers may favor interactive beliefs, they may choose a more pure form of instruction.

When comparing these results with Kinzer's (1988) findings, one notes similarities and differences between elementary and secondary teachers. In both studies, preservice and inservice teachers generally held readerbased and interactive orientations across belief statements and lesson choices; a text-based emphasis was found only for secondary teachers on the decoding lessons. In addition, the relationship between belief 
statements and lesson plans was also similar; teachers in both studies were consistent only when holding readerbased orientations.

However, a major difference between the studies concerned the teachers' relative emphases on reader-based and interactive orientations. Preservice elementary teachers were more consistently reader based than their secondary counterparts, perhaps because of course and field experience differences in elementary and secondary education curricula. In addition, inservice elementary teachers held fewer reader-based orientations and were less consistent across instruments than were inservice secondary teachers. It may be that classroom conditions for elementary reading (e.g., use of basal texts, school/ district required skill objectives) are prohibitive to belief-supported instruction (e.g., a whole-language approach). In contrast, inservice secondary teachers may have fewer external constraints that restrict the implementation of their instructional choices.

Overall, these results provide some support for research that suggests that teachers' theoretical orientations about the reading process are reflected in their instructional decision making (Stern \& Shavelson, 1983). Given the limitations of the present research, in future studies we will examine the beliefs and choices of secondary teachers in relation to their actual practice, that is, a comparison among what they believe, what lessons they choose, and what they do in real classrooms. In addition, teachers' selection of individual belief statements, in addition to their broad theoretical orientations, will be examined in light of their observed plans and activities. Further, these studies will focus on separate content areas in order to investigate possible differences according to subject discipline. By studying these components we hope to better describe the complexities of the teaching and learning experience.

\section{APPENDIX A}

\section{Beliefs Regarding How One Reads*}

1. Before students can comprehend a text, they must be able to recognize all the words and/or symbols in a textbook page.

2. Students' background knowledge and experience play a major role in their comprehension of a text.

3. Students who are weak at word-recognition skills usually cannot compensate for this weakness with other components of the reading process.

4. Before students read a text, it is often useful for them to discuss experiences involving the topic being studied.

5. There is usually only one acceptable answer to a question from a text.

6. Teachers should normally provide instruction aimed at developing all components of the reading process.

7. If students are weak in one component important to the com- prehension process, it is still possible for them to read and comprehend a text.

8. The meaning of a text is usually a joint product of reader knowledge and text information.

9. Teachers should normally expect and encourage students to have different interpretations of a text.

10. If readers do not comprehend a text in the way an author intended, we usually say they have misunderstood the text.

11. Teachers should normally discuss with students what they know about a topic before they begin reading a text.

12. When students summarize a text, they should usually restate what the text says.

13. Expectations about a text topic are often as important as accurate recognition of words during the reading process.

14. Readers use a variety of strategies as they read a text-from sounding out unfamiliar words to guessing familiar words in rich context.

15. The best readers of a text are those who have learned to predict upcoming text.

*Text-based statements: $1,3,5,10,12$; reader-based statements: 2,4 , $9,11,15$; interactive statements: $6,7,8,13,14$.

\section{Beliefs Regarding How Reading Develops*}

1. It is important for content teachers to provide clear, precise presentations during skill instruction.

2. Students should receive many opportunities to read materials other than the textbook in the content areas (e.g., newspapers, literature, magazines).

3. In deciding how to teach a text topic, teachers should consider the varying abilities of the students.

4. Reading, writing, speaking, and listening are closely related learning processes.

5. Students learn content best when the material is broken down into specific skills to be iaught by teachers.

6. Students should be tested frequently to determine if they have mastered what was taught.

7. Some students learn best by reading widely and often; others learn best through direct instruction.

8. Teachers should model how to learn from text material so that students gradually acquire their own independent reading strategies.

9. Opportunities should be created in the content areas to encourage students to read.

10. Not all poor readers benefit from more direct and structured learning experiences.

11. Teachers should have a list of reading skills appropriate for their content area and make certain that students learn these skills.

12. Much of what is learned in the content areas can be attributed to what is taught by the teacher.

13. It is important to consider students' differing reading abilities when selecting and using text materials. 
14. Students can acquire a great deal of knowledge about learning to learn through adult models.

15. Teachers should generally spend more time working with less proficient readers than with more proficient readers.

*Text-based statements: $1,5,6,11,12$; reader-based statements: 2,4 , $8,9,14$; interactive statements: $3,7,10,13,15$.

\section{APPENDIX B}

\section{Vocabulary Lesson Plans*}

The teacher identifies several terms which may be unfamiliar to the students as they read the text. The teacher decides to utilize the following procedure:

\section{Lesson 1}

1. The teacher explains that the students may be unfamiliar with some of the words they encounter in the upcoming reading selection. The teacher writes the words on the board and recites them to the students. The students are asked to provide definitions for the words.

2. The teacher has prepared a transparency with the words used in sentences. Using the context of the sentence, the students attempt to provide definitions for the words. The teacher provides the correct definitions for any not provided by the students and asks them to use each word in a sentence.

3. Before the students begin the reading assignment, the teacher provides a brief overview of the material. With this information, the students are asked to predict the usage of the new vocabulary word in the text.

4. After reading the text selection, the students write the vocabulary words and definitions in their own words in their notebooks.

5. The students are asked to write a passage using the terms. The teacher provides the topics according to the students' abilities.

6. The following day, the students take a quiz that involves matching some definitions with the words. The students use the other words by writing their own sentences.

\section{Lesson 2}

1. Before the students read the text, the teacher explains that the student may be unfamiliar with some of the words they will encounter in the upcoming reading selection.

2. The teacher writes these words on the board and asks the students to use the words in sentences. If some of the words are unfamiliar to the students, the teacher uses those words in sentences and asks the students to define them by using the context of the sentences.

3. Then the teacher asks the students to describe situations where they may have encountered or read about the terms. The teacher asks other students how these situations may be familiar to them. Then the students are asked to apply the definitions to other possible situations.

4. Following the discussion, the teacher provides different materials which contain the words used in a variety of ways. The class works in groups, analyzing the material and engaging in discussion about the meaning of the terms.

5. After reading the text selection, the students are asked to discuss their interpretations of the reading and the vocabulary words.

6. The following day, for a quiz grade, the students are asked to convey the meaning of the words in any type of writing passage.

\section{Lesson 3}

1. The teacher writes the vocabulary words on the board and reads the words aloud. The students are asked to recite the words and provide definitions. The teacher writes the correct student definitions and any that were not provided by the students on the board

2. Then the teacher shows the students a transparency with the terms used in sentences. The students are asked to read each sentence aloud and recite the meanings of the new terms.
3. The teacher has prepared another transparency with sentences and missing words. The students are asked to fill in the blanks with the appropriate vocabulary words.

4. After this exercise, the students are asked to read the text selection. On a transparency, the teacher has written the sentences from the text containing the vocabulary words, leaving a blank where the term belongs. The class is asked to fill in the blanks and provide definitions of the terms.

5. Students are instructed to write the terms and the teacher's definitions in their notebooks.

6. The following day, the students are given a multiple-choice quiz-the vocabulary word is provided as well as three possible choices. For each question answered incorrectly, the students are required to write each term and its definition five times.

*Lesson 1: interactive; Lesson 2: reader based; Lesson 3: text based.

\section{APPENDIX C}

Frequencies of Statement Selection for How Reading Takes Place and How Reading Develops: Preservice and Inservice Teachers

\begin{tabular}{|c|c|c|c|}
\hline $\begin{array}{l}\text { Belief } \\
\text { statement }\end{array}$ & Pre & In & Total \\
\hline \multicolumn{4}{|c|}{ How reading takes place } \\
\hline 1 & 18 & 6 & 24 \\
\hline 2 & 43 & 38 & 81 \\
\hline 3 & 8 & 0 & 8 \\
\hline 4 & 29 & 29 & 58 \\
\hline 5 & 0 & 0 & 0 \\
\hline 6 & 41 & 23 & 64 \\
\hline 7 & 25 & 20 & 45 \\
\hline 8 & 31 & 23 & 54 \\
\hline 9 & 31 & 20 & 51 \\
\hline 10 & 1 & 2 & 3 \\
\hline 11 & 19 & 25 & 44 \\
\hline 12 & 5 & 3 & 8 \\
\hline 13 & 13 & 12 & 25 \\
\hline 14 & 24 & 28 & 52 \\
\hline 15 & 2 & 1 & 3 \\
\hline Total & 290 & 230 & 520 \\
\hline \multicolumn{4}{|c|}{ How reading develops } \\
\hline 1 & 21 & 10 & 31 \\
\hline 2 & 47 & 40 & 87 \\
\hline 3 & 27 & 31 & 58 \\
\hline 4 & 37 & 35 & 72 \\
\hline 5 & 8 & 4 & 12 \\
\hline 6 & 11 & 7 & 18 \\
\hline 7 & 10 & 7 & 17 \\
\hline 8 & 12 & 20 & 32 \\
\hline 9 & 43 & 31 & 74 \\
\hline 10 & 5 & 6 & 11 \\
\hline 11 & 11 & 4 & 15 \\
\hline 12 & 8 & 2 & 10 \\
\hline 13 & 25 & 21 & 46 \\
\hline 14 & 13 & 10 & 23 \\
\hline 15 & 12 & 2 & 14 \\
\hline Total & 290 & 230 & 520 \\
\hline
\end{tabular}

\section{REFERENCES}

Armour-Thomas, E. (1989). The application of teacher cognition in the classroom: A new teaching competency. Journal of Research 
and Development in Education, 22, 29-37.

Clark, C. M., \& Peterson, P. L. (1986). Teachers' thought processes. In M. C. Wittrock (Ed.), Handbook of research on teaching (pp. 255-296). New York: Macmillan.

Duffy, G., \& Anderson L. (1982). Final report: Conceptions of reading progress (Research series No. 11). East Lansing, MI: Institute for Research on Teaching, Michigan State University.

Duffy, G., \& Ball, D. (1986). Instructional decision-making and reading teacher effectiveness. In J. Hoffman (Ed.), Effective teaching of reading: Research and practice (pp. 163-180). Newark, DE: International Reading Association.

Goodman, K. S. (1985). Unity in reading. In H. Singer \& R. Ruddell (Eds.), Theoretical models and processes of reading (3rd ed., pp. 813-840). Newark, DE: International Reading Association.

Gough, P. (1985). One second of reading. In H. Singer \& R. Ruddell (Eds.), Theoretical models and processes of reading (3rd ed., pp. 661-686). Newark, DE: International Reading Association.

Harste, J. C., \& Burke, C. L. (1977). A new hypothesis for reading teacher research: Both the teaching and learning of reading are theoretically based. In P. D. Pearson (Ed.), Reading: Theory, research, and practice (pp. 32-40). Clemson, SC: National Reading Conference.

Hoffman, J. V., \& Kugle, C. L. (1982). A study of theoretical orientation to reading and its relationship to teacher verbal feedback during reading instruction. Journal of Classroom Interaction, 18, 2-7.

Kinzer, C. K. (1988). Instructional frameworks and instructional choices: Comparisons between preservice and inservice teachers. Journal of Reading Behavior, 20, 357-377.

Kinzer, C. K., \& Carrick, D. A. (1986). Teacher beliefs as instruc- tional influences. In J. Niles \& R. Lalik (Eds.), Solving problems in literacy: Learners, teachers \& researchers (pp. 127-134). New York: National Reading Conference.

Lampert, M. (1985). How do teachers manage to teach? Perspectives on problems in practice. Harvard Educational Review, 55, 178-194.

Leu, D. J., \& Kinzer, C. K. (1987). Effective reading instruction in the elementary grades. Columbus, $\mathrm{OH}$ : Merrill.

Marascuilo, L. A. (1966). Large-sample multiple comparisons. Psychological Bulletin, 65, 280-290.

Richardson, V., Anders P., Tidwell, D., \& Lloyd, C. (1991). The relationship between teachers' beliefs and practices in reading comprehension instruction. American Educational Research Journal, $28,559-586$.

Rumelhart, D. E. (1985). Toward an interactive model of reading. In H. Singer \& R. Ruddell (Eds.), Theoretical models and processes of reading (3rd ed., pp. 722-750). Newark, DE: International Reading Association.

Rupley, W. H., \& Logan, J. W. (1984). Elementary teachers' beliefs about reading and knowledge of reading content. (ERIC Document Reproduction No. ED 258 162)

Shavelson, R. J., \& Stern, P. (1981). Research on teachers' pedagogical thoughts, judgments, decisions, and behavior. Review of Educational Research, 51, 455-498.

Shulman, L. S. (1986). Those who understand: Knowledge growth in teaching. Educational Researcher, 15, 4-14.

Stern, P., \& Shavelson, R. (1983). Reading teachers' judgment, plans, and decision-making. The Reading Teacher, 37, 280-286. 